\title{
Seasonal Changes in the Carbohydrate Pool of an Atlantic Forest Soil under Different Vegetation Types
}

\author{
Variación estacional de los carbohidratos en un suelo forestal de la región atlántica \\ desarrollado bajo diferentes tipos de vegetación \\ Variação sazonal dos hidratos de carbono num solo florestal da região Atlântica \\ desenvolvido sob diferentes tipos de vegetação
}

\section{AUTHORS}

Received: 12.05.2011 | Revised: 08.09.2011 | Accepted: 11.09.2011

\section{Martín A. ${ }^{1 \oplus}$}

amartin@iiag.csic. es

\section{Díaz-Raviña M.}

\section{Carballas T.}

\section{(a) Corresponding}

Author

${ }^{1}$ Instituto de Investigaciones Agrobiológicas de Galicia (IIAG-CSIC) Avda. de Vigo, $s / n$. 15706 Santiago de Compostela (A Coruña, Spain).

\begin{abstract}
The seasonal variations of the content and composition of soil carbohydrates, a labile pool of the soil organic matter, were studied in a Humic Cambisol located within the Atlantic temperate-humid zone (Galicia, N.W. of Spain) and developed over basic schists and under different type of vegetation: Quercus robur (climax forest), Pinus pinaster and Eucalyptus globulus. Soil samples from the A horizon (0-15 cm depth) of the three different forests were collected in spring, summer, autumn and winter. The carbohydrate content was estimated by colorimetry after their extraction by a sequential two-step acid hydrolysis method and further purification of the hydrolysates (first hydrolysis fraction, FA, non-cellulosic polysaccharides; second hydrolysis fraction, FB, cellulosic polysaccharides). The total amount of neutral sugars (hexoses and pentoses) from the three forests was in the range of 2.9-27.4 $\mathrm{g} \mathrm{kg}^{-1}$ d.w., and represented between 5 and $12 \%$ of the total organic C. The carbohydrate content was much higher in the FA fraction than that in the FB fraction, hexoses predominating. over pentoses in both fractions. Seasonal variations of hexoses and pentoses exhibited the same behaviour pattern, showing that for FA and FB fractions higher concentrations of both neutral sugars were found in spring and winter (mean values: 12 and $14 \mathrm{~g}$ total neutral sugars $\mathrm{kg}^{-1} \mathrm{~d} . \mathrm{w}$. , respectively) than in summer and autumn ( 7 and $8 \mathrm{~g}$ total neutral sugars $\mathrm{kg}^{-1} \mathrm{~d}$.w., respectively). Likewise, for each year's season, the total content of both hexoses and pentoses in both fractions varied in the order: Quercus (16 g neutral sugars $\mathrm{kg}^{-1}$ d.w.) > Pinus $\left(9 \mathrm{~g}\right.$ neutral sugars $\mathrm{kg}^{-1} \mathrm{~d}$.w. $)>$ Eucalyptus $(5 \mathrm{~g}$ neutral sugars $\mathrm{kg}^{-1}$ d.w.) forests. Vegetation type clearly affected soil organic carbon, carbohydrate content and aggregate stability, while the ratio neutral sugar $\mathrm{C} /$ total organic $\mathrm{C}$ was mostly affected by season. Compared to the climax oak forest, the pine and eucalyptus stands exhibited a significant reduction in the content of carbohydrates, total organic $\mathrm{C}$, total $\mathrm{N}$ and in aggregate stability, showing a decrease in soil quality.
\end{abstract}

\section{RESUMEN}

Las variaciones estacionales del contenido y composición de los carbohidratos del suelo, una de las fracciones lábiles de la material orgánica del suelo, fueron estudiadas en un Cambisol Húmico localizado en la zona templadobúmeda Atlántica (Galicia, N.O. de España) y desarrollado sobre esquistos básicos y bajo diferente tipo de vegetación: Quercus robur (bosque climax), Pinus pinaster y Eucalyptus globulus. Se recogieron muestras de suelo del horizonte A (0-15 cm de profundidad) de los tres bosques en primavera, verano, otoño e invierno. El contenido en carbobidratos se determinó por métodos colorimétricos, después de su extracción por el método de hidrólisis ácida en dos etapas sucesivas y posterior purificación de los hidrolizados obtenidos (FA, primera fracción de hidrólisis, polisacáridos no celulósicos; FB, segunda fracción de hidrólisis, polisacáridos celulósicos). El contenido total en 
azúcares neutros (hexosas y pentosas) de los tres bosques se encuentra dentro del rango de 2,9-27,4 $\mathrm{g} \mathrm{kg}^{-1}$ s.s., $y$ representa entre el 5 y el $12 \%$ del C orgánico total del suelo. La concentración de carbohidratos fue mucho mayor en la fracción $F A$ que en la fracción FB, predominando las hexosas sobre las pentosas en ambas fracciones. Las variaciones estacionales de las hexosas y las pentosas mostraron el mismo tipo de comportamiento en las fracciones FA y FB, presentando mayores concentraciones de estos azúcares neutros en primavera e invierno (valores medios: 12 y $14 \mathrm{~g}$ azúcares neutros $\mathrm{kg}^{-1}$ s.s., respectivamente) que en verano y otoño (7 y $8 \mathrm{~g}$ azúcares neutros $\mathrm{kg}^{-1}$ s.s., respectivamente). Asimismo, en cada estación del año, el contenido total de hexosas y pentosas en ambas fracciones de los tres bosques siguió el orden: Quercus (16 $\mathrm{g}$ azúcares neutros $\mathrm{kg}^{-1}$ s.s.) > Pinus (9 g azúcares neutros $\mathrm{kg}^{-1}$ s.s.) $>$ Eucalyptus (5 g azúcares neutros $\mathrm{kg}^{-1}$ s.s.). El tipo de vegetación ejerció un claro efecto sobre el carbono orgánico del suelo, el contenido total de carbohidratos y la estabilidad de los agregados, mientras que la estación del año tuvo una mayor influencia sobre la proporción de C orgánico del suelo presente en forma de azúcares neutros. En comparación con el robledal (vegetación climax), se observó que el pinar y el eucaliptal presentaron menor contenido en carbohidratos, $C$ orgánico total y $N$ total y una disminución de la estabilidad de los agregados, lo que demuestra una disminución de la calidad del suelo.

\section{RESUMO}

As variaçôes sazonais no conteúdo e na composição dos hidratos de carbono do solo, uma das fraçôes lábeis da matéria orgânica do solo, foram estudadas num Cambisolo húmico sito na área temperado-búmida Atlântica (Galiza, N.O. da Espanha) e desenvolvido sobre xistos básicos e sobre diferentes tipos de vegetação: Quercus robur (floresta climax), Pinus pinaster e Eucalyptus glóbulos. Foram colbidas amostras de solo do horizonte A (camada de 0-15 $\mathrm{cm}$ de profundidade) das três florestas, na Primavera, Verão, Outono e Inverno. O conteúdo de hidratos de carbono foi determinado pelo método colorimétrico, após extração com hidrólise ácida em duas etapas sucessivas e posterior purificação dos hidrolisados (FA, primeira fração da hidrólise, polissacarídeos não celulósicos; FB, segunda fração da hidrólise, polissacarídeos celulósicos). O conteúdo total de açúcares neutros (hexoses e pentoses) das três florestas encontra-se entre 2,9 e 27,4 $\mathrm{g} \mathrm{kg}^{-1}$ s.s., e representa entre 5 e $12 \%$ do C orgânico total do solo. A concentração de bidratos de carbono foi muito maior na fração $F A$ no que na fração $F B$, predominando as hexoses sobre as pentoses em ambas as fraçôes. As variaçôes sazonais das hexoses e pentoses mostraram o mesmo tipo de comportamento nas fraçôes FA e FB, apresentando maiores concentrações destes açúcares neutros na Primavera e no Inverno (conteúdos médios: 12 e $14 \mathrm{~g}$ açúcares neutros totais $\mathrm{kg}^{-1}$ s.s., respectivamente) do que no Verão e no Outono (7 e $8 \mathrm{~g}$ açúcares neutros totais $\mathrm{kg}^{-1}$ s.s., respectivamente). Alem disso, para cada estação do ano, o conteúdo total de hexoses e pentoses em ambas as fraçôes das três florestas foi como se mostra a seguir: Quercus (16 $\mathrm{g}$ açúcares neutros $\mathrm{kg}^{-1}$ s.s.) $>$ Pinus (9 $\mathrm{g}$ açúcares neutros $\mathrm{kg}^{-1}$ s.s.) > Eucalyptus ( $5 \mathrm{~g}$ açúcares neutros $\mathrm{kg}^{-1}$ s.s.). O tipo de vegetação teve efeito sobre 0 carbono orgânico do solo, o conteúdo total de hidratos de carbono e a estabilidade dos agregados; porém, a estação do ano teve a maior influência na porcentagem de C orgânico do solo na forma de açúcares neutros. Comparativamente com o carvalhal (vegetação climax), observou-se que o pinhal e a floresta do Eucalipto tinham menos conteúdo de hidratos de carbono, carbono orgânico total e azoto total, e a estabilidade aos agregados fora menor, o que demonstra uma diminuição da qualidade do solo. 


\section{Introduction}

Soil carbohydrates represent between 5 and 25 $\%$ of the soil organic matter (SOM), the higher values corresponding to soils with high contents in SOM, such as peats and podzols (Cheshire 1979). They mainly came from plant debris, root exudates, microorganisms and animal residues; their content is variable depending on the type of soil and soil management practices (Stevenson 1982). The polysaccharides of vegetal or microbial origin are the most abundant carbohydrates in soils, being hexoses the major components of these compounds, followed by pentoses and deoxy-hexoses (Cheshire 1979). Although it is difficult to establish the specific origin of each of these compounds, generally it is considered that plants are the main source of soil pentoses while hexoses and deoxy-hexoses are synthesized by both plants and soil microorganisms (Cheshire 1979; Kawahigashi et al. 2003), whereas to attribute a specific origin to some sugars, such as glucose and ribose, is not possible (Cheshire 1979; Tanaka et al. 1995). Some carbohydrates play an important role in soils due to its intervention in the formation of an adequate soil structure for plant development and its contribution to microorganism's nutrition (Stevenson 1982; Cheshire 1985; Schnitzer 1991; Haynes and Francis 1993; Puget et al. 1999; Debosz et al. 2002).

In the development of forest ecosystems, SOM plays a fundamental role. Its dynamics depends to a great extent on both biotic (vegetation, microbial mass and activity) and abiotic (temperature, precipitation, parent material, topography) factors (Kawahigashi et al. 2003), as well as land-use and soil management. Several investigations have shown the relevance of studying the labile fractions of the SOM as sensitive early indicators of environmental conditions and land use changes and soil management, before these changes can be detected in recalcitrant organic fractions or in the total soil C (Gregorich et al. 1994; Currie et al. 1996; Haynes 2000; Kaiser et al. 2001; Debosz et al. 2002; Kawahigashi et al. 2003; Jolivet et al. 2006; Spielvogel et al. 2007; van Hees et al. 2008). In this way, studies on content and composition of carbohydrates, one of the labile pools of the SOM, have provided valuable information on its vegetal or microbial origin (Oades 1984; Kaiser et al. 2001; Debosz et al. 2002; Rovira and Vallejo 2002), its lability and hence its importance in SOM dynamics (Murata et al. 1998, 1999; Debosz et al. 2002; Rovira and Vallejo 2002; Kawahigashi et al. 2003; van Hees et al. 2008) as well as its usefulness as an index of changes in SOM in forest soils degraded by wildfires and other disturbances (Spielvogel et al. 2007; Martín et al. 2009). However, in spite of its interest, information concerning the content and composition of soil carbohydrates in forest soils from the Spanish humid-temperate zone is very scarce, and the influence of tree species and season on this labile fraction of the SOM has not been evaluated yet.

Galicia, located in the NW of Spain, is a mountainous region with 2,000,000 ha of forest land with scrub and tree stands, developed on a complex mosaic of soil types and parent materials. The Quercus robur forest is the climax vegetation; however, these forests have supported various great deforestations mainly due to the use of oak wood in the construction of ships for the navy and sleepers for the railway. In the decade of 1950 the damages produced in these forests were intended to be counteracted with a massive reforestation made with monoespecific communities of pines and eucalyptus. Although this action has protected the soils against erosion, it provoked a negative effect by favouring forest fires, which have increased in number, extension and severity, provoking soil degradation and post-fire erosion due to the presence of deep slopes in this mountainous region. Nowadays, although the majority of the territory is covered by pine and eucalyptus stands, oak forests remained in some broad zones and its extension is being boosted and protected (Carballas et al. 2009).

The aim of this work was to determine if seasonal fluctuations over the year and changes in the tree species modify the content and composition of soil carbohydrates and the soil quality in a soil developed under a climax forest. 


\section{Material and Methods}

\section{Site description}

The study area was located in Galicia (NW of Spain) within the Atlantic humid temperate zone. In a broad area sited in the councils of Abegondo and Cambre (29TNH5988 and 29TNH5793, respectively) (Forest district II, Province of $A$ Coruña) with a Humic Cambisol (HC; World Reference Base for Soil Resources - WRB 2007) developed over basic schist, three forests were selected for the study: an oak forest ( $\mathrm{HC1}$ ), with 100 to 150-years-old Quercus robur L. (climax forest taken as reference); a pine stand (HC2), with 40 to 50-years-old Pinus pinaster L.; and an eucalyptus stand (HC3), with 25 to 30-yearsold Eucalyptus globulus L. (the two latter stands having been established after deforestation of part of the oak forest in the same area). The three forests were at 30-90 $\mathrm{m}$ a.s.l. in almost flat sites. The climate data of the area taken from the closest meteorological station (Mabegondo, A Coruña) were: $13 \pm 4^{\circ} \mathrm{C}$ mean monthly air temperature -minimum $7^{\circ} \mathrm{C}$, maximum $19^{\circ} \mathrm{C}$ - and $80 \pm 66 \mathrm{~mm}$ of total monthly precipitation - minimum $8 \mathrm{~mm}$, maximum $200 \mathrm{~mm}$. The highest temperature $\left(19.2 \pm 0.3^{\circ} \mathrm{C}\right)$ was reached in summer (July-August) and the lowest $\left(8.2 \pm 0.8^{\circ} \mathrm{C}\right)$ in winter (December-February) whereas the events of most precipitation were registered in autumn and winter (38 and $42 \%$ of the annual precipitation, respectively) and those of less precipitation in spring (16\%) and summer (8\%).

\section{Soil sampling}

The soil was sampled in the three forests with different vegetation at each season of the year: spring (s), summer (su), autumn (a) and winter (w). In each forest type, three plots of $6 \mathrm{~m} \times 3$ $\mathrm{m}$ were established. In each plot, after removing the litter from the soil, 6-8 soil subsamples were collected at random from the $0-15 \mathrm{~cm}$ layer of the A horizon; they were mixed to form a representative composite sample (2-3 kg) and were maintained refrigerated $\left(4^{\circ} \mathrm{C}\right)$ until further processing in the laboratory. After sieving at $2 \mathrm{~mm}$, the fraction $<2 \mathrm{~mm}$, thoroughly homogenised, was used for all subsequent analyses.

\section{Analytical methods}

The methods described by Guitián Ojea and Carballas (1976) were utilised to determine the following properties: moisture content by ovendrying soil samples at $105^{\circ} \mathrm{C}$ for $6-7 \mathrm{~h}$; $\mathrm{pH}$ in $\mathrm{H}_{2} \mathrm{O}$ and $\mathrm{KCl}$ using a soil:solution ratio of 1:2.5; exchangeable cations, cation exchange capacity (CEC) and base saturation (BS) from the extraction with $1 \mathrm{~N}$ ammonium acetate solution at $\mathrm{pH} 7$ for exchangeable $\mathrm{Ca}^{2+}, \mathrm{Mg}^{2+}, \mathrm{K}^{+}$and $\mathrm{Na}^{+}$ and with a triethanolamine- $\mathrm{BaCl}_{2}$ solution at $\mathrm{pH}$ 8.2 for $\mathrm{Al}^{3+}$ and $\mathrm{H}^{+}$; and free $\mathrm{Fe}$ and $\mathrm{Al}$ oxides by extraction with a mixture of Tamm's reagent and sodium dithionite. The $\mathrm{H}^{+}$ions were measured by potentiometry, $\mathrm{K}^{+}$and $\mathrm{Na}^{+}$by atomic emission spectrophotometry, and $\mathrm{Ca}^{2+}, \mathrm{Mg}^{2+}, \mathrm{Fe}^{3+}$ and $\mathrm{Al}^{3+}$ by atomic absorption spectrophotometry. Inorganic $\mathrm{C}$ was not detected in the samples; therefore, the total organic $\mathrm{C}(\mathrm{Ct})$ content was determined on finely ground samples by combustion in a Carmhograph 12 (Wösthoff). The total N (Nt) was estimated by Kjeldahl digestion. The aggregate stability (AS) of the soils was estimated from the loss of soil with a rain simulator (Soto et al. 1991), which was placed with its outlet pointing downward at a height of $2.5 \mathrm{~m}$ above the soil samples placed on a $0.25 \mathrm{~mm}$ sieve surrounded by a vertical splash collector of $177 \mathrm{~cm}^{2}$ in area; the water was delivered at a rate of $45 \mathrm{~mm} \mathrm{~h}^{-1}$ for $30 \mathrm{~min}$ (an energy input of $24.2 \mathrm{~J} \mathrm{~m}^{-2} \mathrm{~mm}^{-1}$ ) and the material passing through the sieve was estimated at the end of the experiment.

The soil carbohydrate content was estimated by colorimetry after their extraction by a sequential two-step acid hydrolysis and further purification of the hydrolysates, following mainly the method of Oades et al. (1970). The protocol comprises a first step treating the soil with a solution of 5 $\mathrm{N} \mathrm{H}_{2} \mathrm{SO}_{4}$ at $105^{\circ} \mathrm{C}$ for $20 \mathrm{~min}$; the hydrolysate (first hydrolysis fraction, FA) was recovered by centrifugation. In a second step, the residue, previously washed with water, was successively hydrolyzed with $24 \mathrm{~N} \mathrm{H}_{2} \mathrm{SO}_{4}$ at room temperature for $16 \mathrm{~h}$ and with $1 \mathrm{~N} \mathrm{H}_{2} \mathrm{SO}_{4}$ at $105^{\circ} \mathrm{C}$ for $5 \mathrm{~h}$; the hydrolysate (second hydrolysis fraction, $\mathrm{FB}$ ) was also recovered by centrifugation. After the purification of the hydrolysates by cation and anion exchange chromatography (Doutre et al. 
1978; Benzing-Purdie 1980; Martín et al. 2009), the content of hexoses $(H)$ and pentoses $(P)$ in the hydrolysates was estimated by colorimetry, following the anthrone (Doutre et al. 1978) and orcinol (Thomas and Lynch 1961) methods, respectively, whereas the content of neutral sugars (NS) was calculated as the sum of that of $\mathrm{H}$ and $\mathrm{P}$. The carbohydrate concentration was expressed in absolute values, as grams of glucose (Glu unit) for hexoses, or xylose (Xyl unit) for pentoses, per $\mathrm{kg}$ dry soil; and in relative values, as percentage of the soil organic $\mathrm{C}$ content assuming that the percentage of $C$ in both glucose and xylose was 40 per cent. All the results were obtained by triplicate determinations and expressed on the basis of oven-dry $\left(105^{\circ} \mathrm{C}, 24 \mathrm{~h}\right)$ weight of soil (d.w.).

\section{Statistical analysis}

The coefficient of variation among three replicate measurements was usually $<5 \%$. Correlations between the carbohydrate content and other soil variables were analysed by calculating simple linear correlation coefficients using a matrix of data corresponding to soil samples altogether. For the whole data set, the one-way analysis of variance was performed to compare: a) for the same forest, the soil samples collected at different season of the year; and b) for the same season, the soil samples collected from the three forests with different vegetation. A two-way analysis of variance for the whole data set was also performed to determine the percentage of variation attributable to factors season and type of vegetation. The SPSS program (version 15.0) was used for the statistical analyses. To reveal the variations attributed to changes in the tree species, the values of the main soil properties of the Humic Cambisol under pines (HC2) and eucalyptus (HC3) were normalized with respect to those of the Humic Cambisol under the climax vegetation $(\mathrm{HC} 1)$, using the equation $\mathrm{Zij}=[(\mathrm{Xij}-$ $\mathrm{X} / \mathrm{SD}]$, where $\mathrm{Xij}$ is the value for the forest under vegetation $i$ in season $j$, and $X y S D$ are the mean value and the standard deviation, respectively, for all samples from $\mathrm{HC} 1$.

\section{Results and Discussion}

The main characteristics of the soil samples from the Humic Cambisol under different types of vegetation, collected in different seasons of the year, are shown in Table 1. The soil pH was acid and the exchangeable bases content was low; consequently, the soil in the three stands was unsaturated. It exhibited high content in total organic $\mathrm{C}$ and relatively high contents in total $\mathrm{N}$ and in free $\mathrm{Fe}$ and $\mathrm{Al}$ oxides that play an important role in the stability of the SOM (Jacquin et al. 1978; Tanaka et al. 1995; Martín et al. 2011). The aggregate stability measured by loss of soil with a rain simulator was low. Due to the abundance of SOM (Ct and $\mathrm{Nt}$ ), the soil probably has a high water retention capacity. This is in agreement with the moisture content of the soil samples from the three stands in all the seasons of the year, being the soil under the oak stand the one with the highest moisture and total organic $C$ content. (Table 1). All these characteristics, generally associated with poor soils, are representative of the forest soils developed on acidic rocks in the Atlantic humid temperate zone of the NW of Spain; however, the productivity of these soils is fairly high and permits the establishment of good forests. This is attributed to: i) the abundance of SOM and humic substances that contribute to the formation and stabilization of aggregates acting as its main cement, and that induces a high or very high buffer capacity, which avoid significant variations in soil pH; and ii) to the climatic conditions, with abundant and well distributed precipitations and scarce periods of long drought (González-Prieto et al. 1996; González-Prieto and Villar 2003; Carballas et al. 2009; Martín et al. 2011).

The total amount of NS, H and $\mathrm{P}$ in the soil samples from the three stands collected in the four seasons of the year (Table 2), were relatively high (between 2.9 and $27.4 \mathrm{~g} \mathrm{~kg}^{-1}$ ) and lied in the range given by other authors for forest soils (Cheshire 1979; Murayama 1980; Martín et al. 2009). The H/P ratio indicates that hexoses were the major component of the NS of the soil, which is in agreement with different authors (Folsom et al. 1974; Cheshire 1979; Kaiser et al. 2001; Rovira and Vallejo 2002; Larré-Larrouy et al. 2004; Jolivet et al. 2006; van Hees et al. 2008). The total content of NS represented between 4.6 
$\%$ and $11.6 \%$ of the soil organic C (average 8.6 $\pm 2.4 \% \mathrm{Ct}$ ), of which 2.9-8.0 \% Ct (average $5.9 \pm 1.7 \% \mathrm{Ct}$ ) were hexoses and 1.7-3.6 \% Ct (average 2.7 $\pm 0.7 \% \mathrm{Ct}$ ) were pentoses; therefore, the percentage of $\mathrm{Ct}$ in the form of hexoses was also higher than that in the form of pentoses. These relatively high values are within the range given frequently for a wide variety of forest soils (Cheshire 1979; Stevenson 1982; Murayama 1980; Oades 1984; Gregorich et al. 1994; Tanaka et al. 1995; Martín et al. 2009).

Table 1. Main characteristics of the soil samples from a Humic Cambisol developed under an oak forest ( $\mathrm{HC} 1)$, a pine stand ( $\mathrm{HC} 2)$ and an eucalyptus stand (HC3), collected in spring, summer, autumn and winter (mean values of triplicate measurements). A. Mean \pm SD for each forest in different seasons; B. Mean \pm SD for all the forests in the same season. C. Values for each forest in spring

\begin{tabular}{|c|c|c|c|c|c|c|c|c|c|c|c|}
\hline \multirow{2}{*}{$\begin{array}{l}\text { Forest } \\
\text { soil } \\
\text { A } \\
\end{array}$} & Vegetation & \multirow[t]{2}{*}{ Season } & \multirow[t]{2}{*}{$\mathbf{p H}_{\mathbf{H}_{2} \mathbf{O}}$} & $\mathrm{pH}_{\mathrm{KCl}}$ & \multicolumn{2}{|c|}{$\frac{\text { Moisture }}{\mathrm{g} \mathrm{H}_{2} \mathrm{O} \mathrm{kg}^{-1} \text { d.w. }}$} & \multicolumn{2}{|c|}{$\begin{array}{c}\text { Loss of soil \# } \\
\mathrm{g} \mathrm{m}^{-2} \mathrm{~min}^{-1} \\
\end{array}$} & Total $\mathbf{N}$ & \multicolumn{2}{|c|}{ Organic C $\mathrm{C} / \mathrm{N}$} \\
\hline & & & & & & & & & & & \\
\hline \multirow[t]{4}{*}{ HC1 } & \multirow[t]{4}{*}{ oak } & spring & 4.3 & 3.4 & 268 & & 5.2 & & 4.9 & 95 & 19 \\
\hline & & summer & 4.7 & 3.8 & 164 & & 12.1 & & 2.8 & 59 & 21 \\
\hline & & autumn & 4.8 & 3.8 & 218 & & 8.9 & & 3.1 & 60 & 19 \\
\hline & & winter & 5.0 & 3.9 & 294 & & 8.7 & & 2.9 & 63 & 22 \\
\hline $\operatorname{mean} \pm$ SD & & & $4.7 \pm 0.3$ & $3.7 \pm 0.2$ & $236 \pm 57$ & & $9 \pm 3$ & & $3.4 \pm 0.9$ & $69 \pm 17$ & $20 \pm 1$ \\
\hline \multirow[t]{4}{*}{ HC2 } & \multirow[t]{4}{*}{ pine } & spring & 5.0 & 4.0 & 156 & & 13.2 & & 3.0 & 39 & 13 \\
\hline & & summer & 5.0 & 4.0 & 158 & & 15.7 & & 3.2 & 47 & 15 \\
\hline & & autumn & 5.2 & 4.1 & 237 & & 17.6 & & 3.0 & 41 & 14 \\
\hline & & winter & 5.3 & 4.2 & 328 & & 16.3 & & 3.3 & 46 & 14 \\
\hline \multicolumn{2}{|l|}{ mean \pm SD } & & $5.1 \pm 0.1$ & $4.1 \pm 0.1$ & $220 \pm 82$ & & $16 \pm 2$ & & $3.1 \pm 0.2$ & $43 \pm 4$ & $14 \pm 1$ \\
\hline \multirow[t]{4}{*}{ HC3 } & \multirow[t]{4}{*}{ eucalyptus } & spring & 4.8 & 3.6 & 85 & & 17.8 & & 2.3 & 30 & 13 \\
\hline & & summer & 4.9 & 3.6 & 165 & & 46.4 & & 1.7 & 25 & 15 \\
\hline & & autumn & 4.7 & 3.7 & 101 & & 24.5 & & 1.5 & 22 & 14 \\
\hline & & winter & 4.7 & 3.7 & 193 & & 16.7 & & 1.8 & 24 & 13 \\
\hline \multicolumn{2}{|l|}{ mean \pm SD } & & $4.7 \pm 0.1$ & $3.6 \pm 0.0$ & $136 \pm 51$ & & $26 \pm 14$ & & $1.8 \pm 0.3$ & $25 \pm 4$ & $14 \pm 1$ \\
\hline \\
\hline \multicolumn{2}{|l|}{ mean \pm SD } & spring & $4.7 \pm 0.4$ & $3.6 \pm 0.3$ & $169 \pm 92$ & & $12 \pm 6$ & & $3.4 \pm 1.3$ & $55 \pm 35$ & $15 \pm 4$ \\
\hline \multicolumn{2}{|l|}{ mean \pm SD } & summer & $4.9 \pm 0.2$ & $3.8 \pm 0.2$ & $162 \pm 4$ & & $25 \pm 19$ & & $2.6 \pm 0.8$ & $44 \pm 17$ & $17 \pm 3$ \\
\hline \multicolumn{2}{|l|}{ mean \pm SD } & autumn & $4.9 \pm 0.3$ & $3.9 \pm 0.2$ & $185 \pm 73$ & & $17 \pm 8$ & & $2.5 \pm 0.9$ & $41 \pm 19$ & $16 \pm 3$ \\
\hline \multicolumn{2}{|l|}{ mean \pm SD } & winter & $5.0 \pm 0.3$ & $3.9 \pm 0.3$ & $272 \pm 70$ & & $14 \pm 4$ & & $2.7 \pm 0.8$ & $45 \pm 20$ & $16 \pm 5$ \\
\hline \multirow{3}{*}{\begin{tabular}{|l|}
$\mathbf{C}$ \\
Forest \\
soil
\end{tabular}} & \multirow[t]{3}{*}{ Vegetation } & \multirow[t]{3}{*}{ Season } & \multicolumn{6}{|c|}{ Exchange complex } & & & \\
\hline & & & $\mathrm{Ca}^{2+}$ & $\mathrm{Mg}^{2+}$ & $\mathbf{K}^{+} \quad \mathbf{N a}^{+}$ & $\mathbf{H}^{+}$ & $\mathbf{A l}^{3+}$ & CEC & BS & $\mathrm{Fe}_{2} \mathrm{O}_{3}$ & $\mathbf{A l}_{2} \mathbf{O}_{3}$ \\
\hline & & & \multicolumn{6}{|c|}{$\mathrm{cmol}_{\mathrm{c}} \mathrm{kg}^{-1}$ d.w. } & $\%$ & $\mathrm{~g} \mathrm{~kg}^{-1}$ & d.w. \\
\hline HC1 & oak & spring & 0.5 & 0.8 & 0.3 & 37 & 1.0 & 40 & 6 & 20.5 & 9.8 \\
\hline HC2 & pine & spring & 0.6 & 0.6 & 0.4 & 28 & 0.9 & 30 & 7 & 30.0 & 19.6 \\
\hline HC3 & eucalyptus & spring & 0.8 & 0.4 & 0.5 & 17 & 0.8 & 19 & 12 & 18.9 & 7.7 \\
\hline
\end{tabular}

\#Loss of soil in a rain simulator measured for the estimation of aggregate stability (AS) 
Table 2. Content ( $\mathrm{g} \mathrm{kg}^{-1}$ soil d.w.) and distribution of hexoses $(\mathrm{H})$, pentoses $(\mathrm{P})$ and neutral sugars (NS) and the hexoses/pentoses ratio (H/P) in the two hydrolysis fractions (FA and $\mathrm{FB}$ ) of soil samples from a Humic Cambisol developed under an oak forest (HC1), a pine stand (HC2) and an eucalyptus stand (HC3) collected in spring, summer, autumn and winter (mean values of triplicate measurements). A. Mean $\pm S D$ for each forest in different seasons; $B$. Mean $\pm S D$ for the three forests in the same season

\begin{tabular}{|c|c|c|c|c|c|c|c|c|c|c|c|}
\hline \multirow{2}{*}{ Forest soil } & \multirow{2}{*}{ Season } & \multicolumn{3}{|c|}{ FA } & \multicolumn{3}{|c|}{ FB } & \multicolumn{3}{|c|}{ Total $(F A+F B)$} & \multirow[b]{2}{*}{$\mathbf{H} / \mathbf{P}$} \\
\hline & & H & $\mathbf{P}$ & NS & H & $\mathbf{P}$ & NS & $\mathbf{H}$ & $\mathbf{P}$ & NS & \\
\hline \multicolumn{12}{|l|}{\begin{tabular}{|l|l}
$\mathrm{A}$ \\
\end{tabular}} \\
\hline \multirow[t]{4}{*}{$\mathrm{HC} 1$} & spring & 16.3 & 8.2 & 24.5 & 2.5 & 0.4 & 2.9 & 18.8 & 8.6 & 27.4 & 2.2 \\
\hline & summer & 6.9 & 4.0 & 10.9 & 0.7 & 0.0 & 0.7 & 7.6 & 4.0 & 11.6 & 1.9 \\
\hline & autumn & 6.6 & 2.9 & 9.5 & 0.9 & 0.0 & 0.9 & 7.5 & 2.9 & 10.4 & 2.6 \\
\hline & winter & 10.4 & 3.9 & 14.3 & 1.7 & 0.3 & 2.0 & 12.1 & 4.2 & 16.3 & 2.9 \\
\hline mean \pm SD & & $10 \pm 4$ & $5 \pm 2$ & $15 \pm 7$ & $1 \pm 1$ & $0.2 \pm 0.2$ & $2 \pm 1$ & $11 \pm 5$ & $5 \pm 2$ & $16 \pm 8$ & $2.4 \pm 0.4$ \\
\hline \multirow[t]{4}{*}{ HC2 } & spring & 5.2 & 3.1 & 8.3 & 1.1 & 0.1 & 1.2 & 6.3 & 3.2 & 9.5 & 2.0 \\
\hline & summer & 5.3 & 3.0 & 8.3 & 0.3 & 0.0 & 0.3 & 5.6 & 3.0 & 8.6 & 1.9 \\
\hline & autumn & 3.5 & 2.2 & 5.7 & 0.9 & 0.0 & 0.9 & 4.4 & 2.2 & 6.6 & 2.0 \\
\hline & winter & 7.5 & 4.0 & 11.5 & 1.6 & 0.3 & 1.9 & 9.1 & 4.3 & 13.4 & 2.1 \\
\hline $\operatorname{mean} \pm \mathrm{SD}$ & & $5 \pm 2$ & $3 \pm 1$ & $8 \pm 2$ & $1.0 \pm 0.6$ & $0.1 \pm 0.1$ & $1.1 \pm 0.7$ & $6 \pm 2$ & $3 \pm 1$ & $9 \pm 3$ & $2.0 \pm 0.1$ \\
\hline \multirow[t]{4}{*}{ HC3 } & spring & 3.7 & 2.1 & 5.8 & 0.9 & 0.0 & 0.9 & 4.6 & 2.1 & 6.7 & 2.2 \\
\hline & summer & 1.8 & 1.1 & 2.9 & 0.0 & 0.0 & 0.0 & 1.8 & 1.1 & 2.9 & 1.7 \\
\hline & autumn & 2.2 & 0.9 & 3.1 & 0.3 & 0.0 & 0.3 & 2.5 & 0.9 & 3.4 & 2.7 \\
\hline & winter & 3.8 & 1.8 & 5.6 & 1.0 & 0.2 & 1.2 & 4.8 & 2.0 & 6.8 & 2.4 \\
\hline mean \pm SD & & $3 \pm 1$ & $1 \pm 1$ & $4 \pm 2$ & $0.5 \pm 0.5$ & $0.1 \pm 0.1$ & $0.6 \pm 0.5$ & $3 \pm 1$ & $1 \pm 1$ & $5 \pm 2$ & $2.2 \pm 0.4$ \\
\hline \multicolumn{12}{|l|}{\begin{tabular}{|l|}
$\mathrm{B}$ \\
\end{tabular}} \\
\hline mean \pm SD & spring & $8 \pm 7$ & $4 \pm 3$ & $13 \pm 10$ & $1.5 \pm 0.9$ & $0.2 \pm 0.2$ & $1.7 \pm 1.1$ & $10 \pm 8$ & $5 \pm 3$ & $14 \pm 11$ & $2.1 \pm 0.1$ \\
\hline $\operatorname{mean} \pm \mathrm{SD}$ & summer & $5 \pm 3$ & $3 \pm 1$ & $7 \pm 4$ & $0.3 \pm 0.3$ & $0.0 \pm 0.0$ & $0.3 \pm 0.4$ & $5 \pm 3$ & $3 \pm 1$ & $8 \pm 4$ & $1.8 \pm 0.1$ \\
\hline $\operatorname{mean} \pm \mathbf{S D}$ & autumn & $4 \pm 2$ & $2 \pm 1$ & $6 \pm 3$ & $0.7 \pm 0.3$ & $0.0 \pm 0.0$ & $0.7 \pm 0.3$ & $5 \pm 2$ & $2 \pm 1$ & $7 \pm 3$ & $2.4 \pm 0.4$ \\
\hline mean \pm SD & winter & $7 \pm 3$ & $3 \pm 1$ & $10 \pm 4$ & $1.4 \pm 0.4$ & $0.3 \pm 0.0$ & $1.7 \pm 0.5$ & $9 \pm 4$ & $3 \pm 1$ & $12 \pm 5$ & $2.5 \pm 0.4$ \\
\hline
\end{tabular}

The study of the distribution of the NS in the hydrolysis fractions FA and FB, expressed in absolute values (Table 2) or relative values as percentages of the total soil organic C (Figure 1) has permitted to obtain valuable information on the composition of the carbohydrates, one of the labile fractions of the SOM. The carbohydrates of the first hydrolysis mainly come from the more labile non-cellulosic polysaccharides of plant and microbial origin, whereas those of the second hydrolysis mainly come from the more recalcitrant cellulosic polysaccharides (Oades et al. 1970; Cheshire 1979; Gregorich et al. 1994; Tanaka et al. 1995; Puget et al. 1999; Rovira and Vallejo 2002; Larré-Larrouy et al. 2004). In this study, the NS obtained in the first hydrolysate (FA) represented in average $90 \pm 5 \%$ of the total content, of which $59 \pm 4 \%$ were hexoses and $31 \pm 4 \%$ pentoses, whereas in the second hydrolysate (FB) only a mean value of $10 \pm 5 \%$ of neutral sugars was obtained, of which $9 \pm 4$ $\%$ were hexoses and $1 \pm 1 \%$ pentoses; therefore, the higher percentages of $\mathrm{H}$ and $\mathrm{P}$ were obtained in the first fraction of the hydrolysis, which is in agreement with other authors (Tanaka et al. 1995; Puget et al. 1999; Larré-Larrouy et al. 2004; Rovira and Vallejo 2007). The H/P ratio was significantly higher $(P<0.05)$ in the 
second than in the first hydrolysis fraction (Table 2), suggesting a different contribution of $\mathrm{H}$ and $P$ to the NS in each fraction, in accordance with other authors (Oades et al. 1970; Folsom et al. 1974; Murayama 1980). The low percentage of pentoses in the second hydrolysis fraction (FB) could be due to the predominance in the soil of pentoses coming from the more labile polysaccharides (Cheshire 1979, 1985; Kaiser et al. 2001).

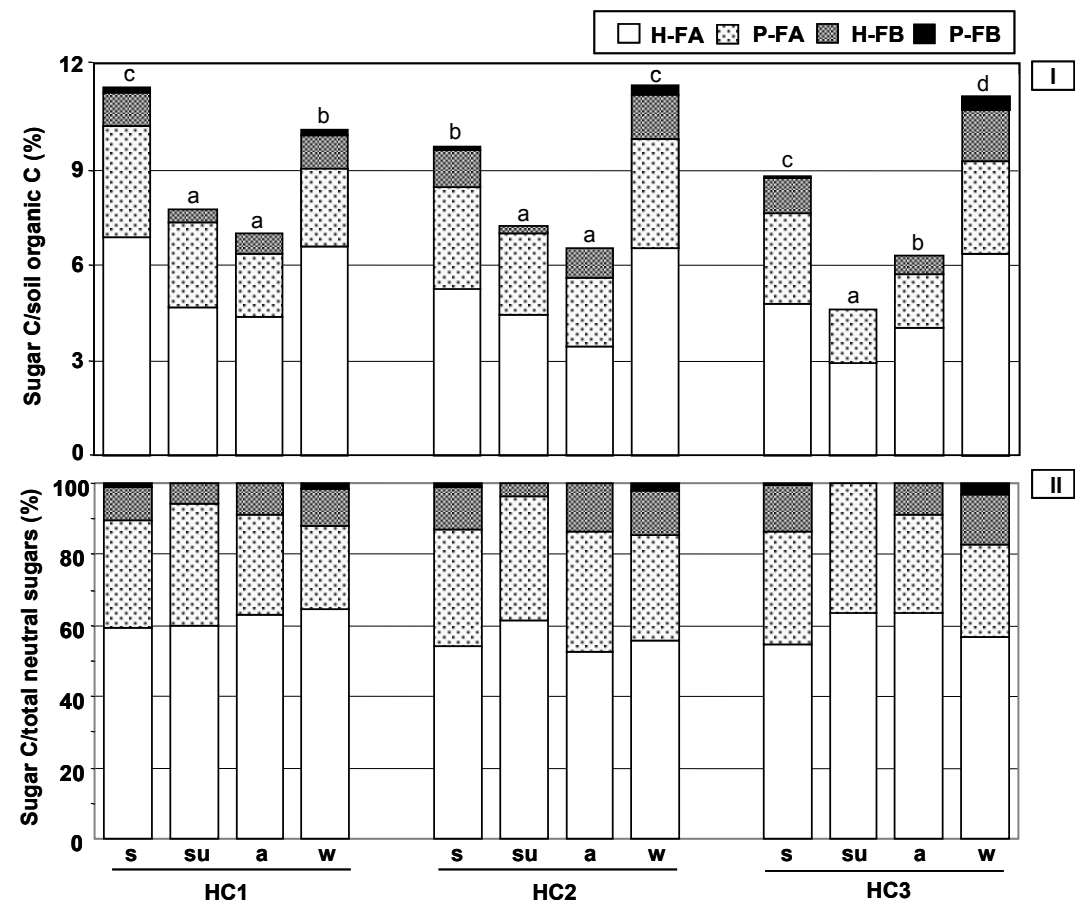

Figure 1. Content and distribution of hexoses $(H)$ and pentoses $(P)$ in the FA and FB hydrolysis fractions of the soil samples from a Humic Cambisol $(\mathrm{HC})$ developed under an oak forest (HC1), a pine stand (HC2) and a eucalyptus stand (HC3), collected in spring (s), summer (su), autumn (a) and winter (w). Sugars content expressed: (I) as percentage of the total soil organic C. (II) as percentage of the total neutral sugars content $(\mathrm{NS}=\mathrm{H}+\mathrm{P})$. For each forest, different letters denote significant differences $(P \leq 0.01)$ among seasons.

The most labile fraction of the carbohydrates, composed by polysaccharides of non-cellulosic origin, represented $7.6 \pm 1.8 \%$ of the total organic $\mathrm{C}$, of which $5.0 \pm 1.3 \%$ correspond to hexoses and $2.6 \pm 0.6 \%$ to pentoses, whereas the most recalcitrant fraction mainly composed by polysaccharides of cellulosic origin, only represented $0.9 \pm 0.6 \%$ of the total organic $C$, being hexoses the majority component $(0.9 \pm 0.5 \%$ $\mathrm{H} ; 0.1 \pm 0.1 \% \mathrm{P})$. The higher proportion of labile forms, more available to the microbiota than the recalcitrant ones, can positively influence the soil microbial activity (Rovira and Vallejo 2002) because the carbohydrates represent the main source of $\mathrm{C}$ and energy for soil microorganisms (Cheshire 1979; Schnitzer 1991; Gregorich et al. 1994; Kalbitz et al. 2003; van Hees et al. 2008); this fact has special relevance for the soils of the temperate humid zone with high content in SOM and low microbial activity (Díaz-Raviña et al. 1988). 
The concentrations of H, P and NS in the analysed soil samples, expressed in absolute values (g kg-1 soil), were positively correlated with the moisture content, organic $\mathrm{Ct}, \mathrm{Nt}$, exchangeable $\mathrm{H}^{+}$ions and CEC, and negatively correlated with BS (Table 3). These correlations seem to indicate that the content in carbohydrates depends mainly on the SOM content ( $\mathrm{C}$ and $\mathrm{N}$ ) and the properties directly related to the organic matter, which is in agreement with other authors (Folsom et al. 1974; Cheshire 1979; Murayama 1984; Angers et al. 1988; Tanaka et al. 1995).

Table 3. Significant correlation coefficients between the soil properties related to the SOM and the variables related to the carbohydrates in the set of the three studied forests

\begin{tabular}{lccc}
\hline Variables & NS & H & P \\
\hline HC/Ct & $0.656^{*}$ & $0.668^{*}$ & $0.612^{*}$ \\
PC/Ct & $0.610^{*}$ & $0.586^{*}$ & $0.653^{*}$ \\
Total N & $0.905^{* *}$ & $0.882^{* *}$ & $0.939^{* *}$ \\
Organic C & $0.911^{* *}$ & $0.907^{* *}$ & $0.900^{* *}$ \\
Loss of soil & $-0.669^{* *}$ & $-0.676^{* *}$ & $-0.639^{* *}$ \\
Moisture & $0.637^{*}$ & $0.655^{*}$ & $0.581^{*}$ \\
H $^{+}$ & $0.679^{*}$ & $0.683^{*}$ & $0.655^{*}$ \\
CEC & $0.676^{*}$ & $0.681^{*}$ & $0.650^{*}$ \\
BS & $-0.660^{*}$ & $-0.654^{*}$ & $-0.659^{*}$ \\
\hline
\end{tabular}

${ }^{*} P<0.01 ; * P<0.05$

A clear effect of the year's season on the soil carbohydrates content, whether it is expressed in $\mathrm{g} \mathrm{kg}^{-1}$ soil or in percentage of $\mathrm{Ct}$, and the $\mathrm{H} / \mathrm{P}$ ratio was observed in all the forests studied (Table 2, Figure 1). In general, the seasonal fluctuations in the content of NS $(H, P)$ showed the same pattern, maximum values being found in spring and/or winter and minimum values in summer and autumn. Similar seasonal changes of carbohydrates in the soil solution or in the soluble OM fraction were also found by Kaiser et al. (2001) and Kawahigashi et al. (2003).
As expected, the pattern of seasonal variations shown by the contents of NS, $\mathrm{H}$ and $\mathrm{P}$ in each hydrolysis fraction, FA and FB, was similar to that shown by the total contents of these carbohydrates in the soil samples from the three forests, with maximum values in spring and/or winter, significantly different $(P \leq 0.01)$ from the minimum values exhibited in summer and/or autumn (Table 2). The seasonal variation of the soil content in total organic C (Table 1), a variable positively correlated with the content in carbohydrates, could partly determine the seasonal fluctuations of the soil carbohydrates. However, the contents in $\mathrm{H}, \mathrm{P}$ and $\mathrm{NS}$, expressed as percentages of the soil organic $\mathrm{C}$, showed a similar seasonal behaviour pattern although with a higher influence of the season (Figure 1). All these facts seem to suggest that other factors besides the amount of soil organic $\mathrm{C}$ determine the seasonal behaviour of the carbohydrates in the soils. In fact, the seasonal variations observed in the studied variables related to carbohydrates can be attributed to fluctuations of climatic factors, such as pluviometry (Guckert and Jacquin 1973) and temperature (Kawahigashi et al. 2003; Spielvogel et al. 2007), soil moisture (Guckert and Jacquin 1973) and litter supply, which modify the number and activity of soil microorganisms (Kawahigashi et al. 2003) and, therefore, the synthesis and degradation of the carbohydrates (Kaiser et al. 2001). This is consistent with the annual fluctuations in microbial biomass observed in soils from the same area, which exhibited maximum values in spring and winter and minimum values in summer and autumn (Díaz-Raviña et al. 1995). Therefore, since marked seasonal fluctuations were observed in the content of NS ( $\mathrm{H}$ and $\mathrm{P}$ ), the time of year is an important factor to take into consideration in order to determine and/or to compare the size of the carbohydrates pool and its relative composition in a wide range of soils and/or in the same soil collected at different sampling times.

The total content in $\mathrm{H}, \mathrm{P}$ and NS, expressed in absolute values $\left(\mathrm{g} \mathrm{kg}^{-1}\right.$ soil), in the three forests followed the order: oak forest $(\mathrm{HC} 1)>$ Pinus stand $(\mathrm{HC} 2)>$ Eucalyptus stand $(\mathrm{HC} 3)$ (Table 2, Figure 1), with significant differences $(P \leq 0.002)$ among them, which seems to show the influence 
of the type of vegetation on the soil carbohydrates. In this sense, Kaiser et al. (2001) attributed the differences observed in the composition of the monosaccharides in forest floor leachates under coniferous and deciduous forests to the different vegetation growing in the soil and the age of stands. Likewise, Folsom et al. (1974) noted that both the vegetation type and the soil microbiota are the main factors responsible for the differences in the composition of soil neutral sugars. In general, the soil samples from the oak forest $(\mathrm{HC} 1)$ presented $\mathrm{H} / \mathrm{P}$ ratios slightly higher than those from the Pinus (HC2) or Eucalyptus (HC3) stands (Table 3), in agreement with other authors (Cheshire et al. 1984; Joergesen and Meyer 1990; Kaiser et al. 2001) who attributed the differences in the H/P ratios to the different vegetation growing in the soils.

In general, seasonal variations were also observed in soil aggregate stability (estimated from the loss of soil in a rain simulator) (Table 1), with maximum values in spring and winter that were significantly different $(P \leq 0.001)$ from the minimum values observed in summer. The type of vegetation also showed a marked influence on soil aggregate stability, corresponding the lower values to the soil samples from the Eucalyptus stand (HC3), followed by those from the Pinus stand ( $\mathrm{HC2}$ ), exhibiting the soil samples from the oak forest $(\mathrm{HC} 1)$ the highest values that were significantly different from the others $(P \leq 0.001)$. These behaviour patterns, which were parallel to that showed by the content in carbohydrates in the soil samples from the three stands with different vegetation, together with the negative correlation found between the loss of soil (measured to estimate the aggregate stability) and the soil contents in $\mathrm{H}, \mathrm{P}$ and NS (Table 3), seem to support the role of the carbohydrates in the formation and stabilization of soil aggregates, as indicated by several authors (Lu et al. 1998; Puget et al. 1999; Larré-Larrouy et al. 2004; Kavdir et al. 2005).

The effect of the study factors, year's season and type of vegetation, on the main soil properties analyzed was tested by means of ANOVA 2 (Table 4). The analysis of variance indicated that the NS content $(\mathrm{H}$ and $\mathrm{P})$ was significantly affect- ed by the season and vegetation, and that these factors were not independent as indicated by the significant effect of the interaction between them (Table 4). The type of vegetation explained most of the variance (44-48\%), the season accounted for $24-25 \%$ and the interaction between both factors explained a further 26-31\% of the variance. For the H/P ratio only a significant effect of the season (54\%) was observed. A similar influence of the analyzed factors was observed for the soil variables related to the carbohydrate pool, such as total organic $\mathrm{C}$, total $\mathrm{N}$ and aggregate stability. For these properties, the vegetation explained $51-80 \%$ of the variation, the season accounted for 7-22 \% of the variation and the interaction between vegetation and season explained a further $13-27 \%$ of the variation. When the NS ( $\mathrm{H}$ and $\mathrm{P})$ values were expressed as percentage of total organic $\mathrm{C}$, the importance of the vegetation as source of variation (2-8\%) decreased notably and increased the season influence (55-73\%), and the interaction between both factors was also significant (20-23\%).

These results seem to show that the type of vegetation was the most determinant factor for all soil properties analyzed. The oak forest exhibited the highest values of organic $\mathrm{Ct}, \mathrm{Nt}$, carbohydrates and aggregate stability, which seems to indicate that these long-term changes in soil properties can be partly attributed to the different tree species planted. Therefore, taking into account that the oak forest is the climax forest of the studied region and that the pine and the eucalyptus stands were established on the same area with the same soil after deforestation of the climax forest, we have studied the consequences of this action on soil quality, comparing the values of the main variables studied in the soil samples from the two stands with those from the oak forest as reference. The results showed that the contents in $\mathrm{Ct}$ and $\mathrm{Nt}$ as well as the aggregate stability (AS), estimated from the loss of soil with a rain simulator, were reduced in the Pinus stand at all seasons of the year (mean percentages of reduction: $34,12,93 \%$, respectively) and that the reduction was much more important in the Eucalyptus stand (63, 36, $200 \%$, respectively) (Figure 2). Similar behaviour was found for the content of $\mathrm{H}$ and $\mathrm{P}$, with decreases 
of 27 and $40 \%$, respectively, in the pine stand; and 70 and $68 \%$, respectively, in the eucalyptus stand (Figure 2). This is consistent with a previous study performed in the same temperate humid zone showing that in a soil developed under three different types of forest (Quercus robur,
Pinus radiata, Eucalyptus nitens) the mass and activity of the microbial component, the most labile SOM fraction with a turnover rate of 1-3 years, followed the order: Quercus > Pinus > Eucalyptus (Álvarez et al. 2009).
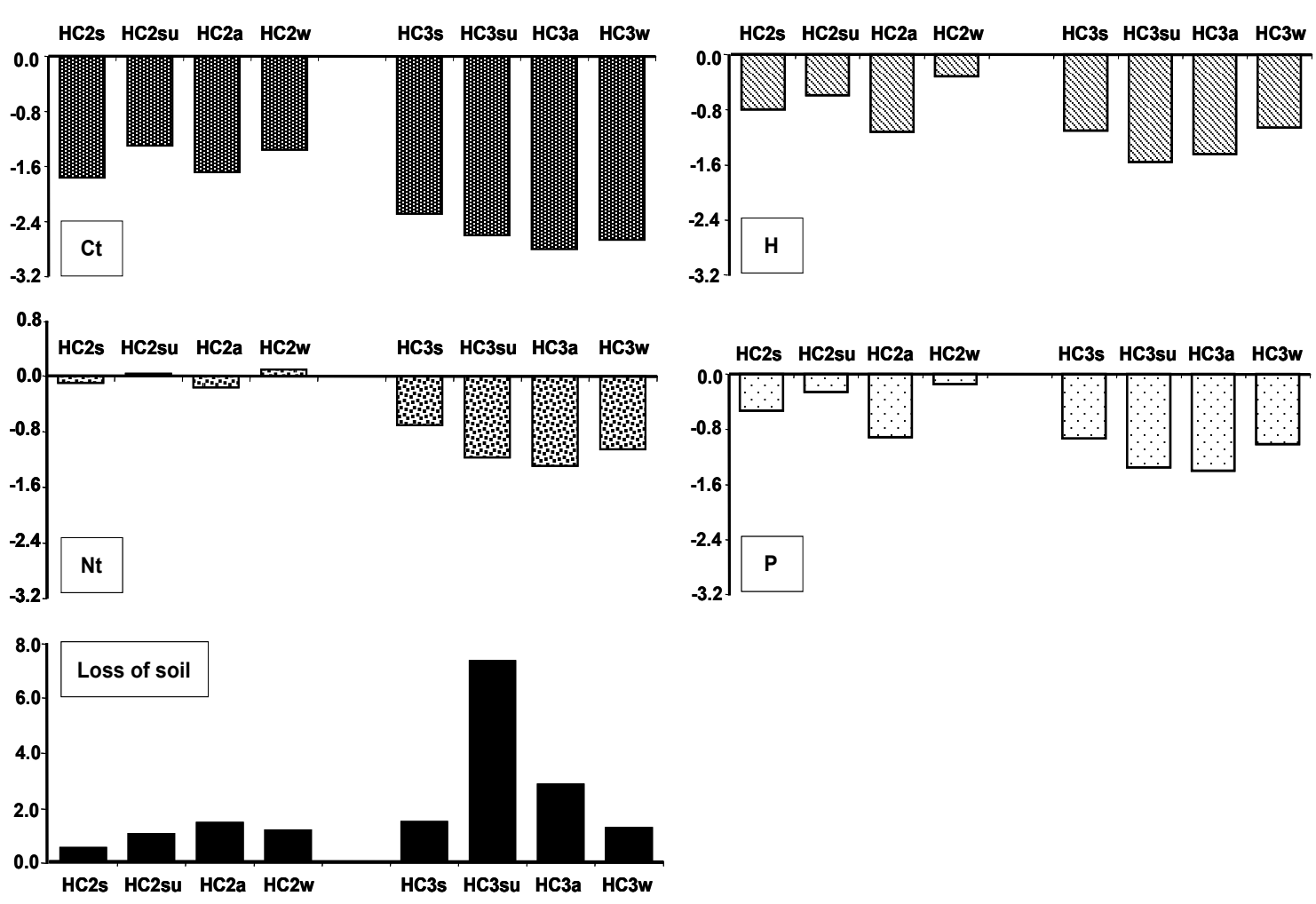

Figure 2. Evolution of the content in total organic $\mathrm{C}(\mathrm{Ct})$; total $\mathrm{N}(\mathrm{Nt})$; loss of soil measured to estimate the aggregate stability (AS); and the content in hexoses $(\mathrm{H})$ and pentoses $(\mathrm{P})$ of soil samples from a Humic Cambisol developed under a pine stand $(\mathrm{HC} 2)$ and a eucalyptus stand (HC3), collected in spring (s), summer (su), autumn (a) and winter (w) (normalised data taking the oak forest as reference). 
Table 4. Two-way analysis of variance (ANOVA2) for the effect of the season of the year and the type of vegetation on: i) the content of neutral sugars (NS), hexoses $(H)$, and pentoses $(P)$ expressed in absolute values ( $\mathrm{g} \mathrm{kg}^{-1} \mathrm{~d}$.w.); ii) the percentage of total soil organic $\mathrm{C}(\mathrm{Ct})$ found in the form of neutral sugars (NSC/Ct), hexoses (HC/Ct), and pentoses (PC/Ct); iii) the hexoses/ pentoses ratio $(\mathrm{H} / \mathrm{P})$; and iv) total organic $\mathrm{C}(\mathrm{Ct})$, total $\mathrm{N}(\mathrm{Nt})$, and the loss of soil, in the soil samples from a Humic Cambisol developed under an oak forest, a pine stand and an eucalyptus stand, collected in different seasons of the year (spring, summer, autumn, and winter)

\begin{tabular}{|c|c|c|c|c|c|}
\hline \multirow[t]{2}{*}{ Variables } & \multirow[t]{2}{*}{ Source of variation } & \multirow[t]{2}{*}{ df } & \multirow[t]{2}{*}{ SS } & \multirow[t]{2}{*}{ F ratio } & \multirow{2}{*}{$\begin{array}{c}\begin{array}{c}\text { Proportion of } \\
\text { variation }\end{array} \\
(\%)\end{array}$} \\
\hline & & & & & \\
\hline \multirow[t]{3}{*}{ NS } & Season & 3 & 240 & $373^{* * *}$ & 25 \\
\hline & Vegetation & 2 & 460 & $1073^{* * *}$ & 47 \\
\hline & Season $\times$ Vegetation & 6 & 268 & $209 * * *$ & 28 \\
\hline \multirow[t]{3}{*}{$\mathbf{H}$} & Season & 3 & 120 & $276^{* * *}$ & 25 \\
\hline & Vegetation & 2 & 231 & $796^{* * *}$ & 48 \\
\hline & Season $\times$ Vegetation & 6 & 125 & $143^{* * *}$ & 26 \\
\hline \multirow[t]{3}{*}{$\mathbf{P}$} & Season & 3 & 40 & $96^{* * *}$ & 24 \\
\hline & Vegetation & 2 & 22 & $257^{* * *}$ & 44 \\
\hline & Season $\times$ Vegetation & 6 & 28 & $61^{* * *}$ & 31 \\
\hline \multirow[t]{3}{*}{$\mathbf{H} / \mathbf{P}$} & Season & 3 & 2 & $6^{*}$ & 54 \\
\hline & Vegetation & 2 & 1 & 1 & 19 \\
\hline & Season $\times$ Vegetation & 6 & 1 & 3 & 19 \\
\hline \multirow[t]{3}{*}{$\mathrm{SNC} / \mathrm{Ct}$} & Season & 3 & 91 & $175^{* * *}$ & 68 \\
\hline & Vegetation & 2 & 11 & $31^{* * *}$ & 8 \\
\hline & Season $\times$ Vegetation & 6 & 30 & $28^{* * *}$ & 22 \\
\hline \multirow[t]{3}{*}{$\mathrm{HC} / \mathrm{Ct}$} & Season & 3 & 51 & $159^{* * *}$ & 73 \\
\hline & Vegetation & 2 & 4 & $17^{* * *}$ & 5 \\
\hline & Season $\times$ Vegetation & 6 & 14 & $22^{* * *}$ & 20 \\
\hline \multirow[t]{3}{*}{$\mathrm{PC} / \mathrm{Ct}$} & Season & 3 & 7 & $71^{* * *}$ & 55 \\
\hline & Vegetation & 2 & 2 & $38^{* * *}$ & 2 \\
\hline & Season $\times$ Vegetation & 6 & 3 & $15^{* * * *}$ & 23 \\
\hline \multirow[t]{3}{*}{$\mathrm{Ct}$} & Season & 3 & 1008 & $710^{* * * *}$ & 7 \\
\hline & Vegetation & 2 & 11736 & $12404^{* * * *}$ & 80 \\
\hline & Season $\times$ Vegetation & 6 & 1855 & $654^{* * * *}$ & 13 \\
\hline \multirow[t]{3}{*}{ Nt } & Season & 3 & 4 & $224^{* * *}$ & 16 \\
\hline & Vegetation & 2 & 17 & $1316^{* * *}$ & 64 \\
\hline & Season $\times$ Vegetation & 6 & 5 & $131^{* * * *}$ & 19 \\
\hline \multirow[t]{3}{*}{ Loss of soil " } & Season & 3 & 844 & $405^{* * *}$ & 22 \\
\hline & Vegetation & 2 & 1902 & $1371^{* * *}$ & 51 \\
\hline & Season $\times$ Vegetation & 6 & 975 & $234 * * *$ & 27 \\
\hline
\end{tabular}

df, Degrees of freedom; SS, Sums of squares. ${ }^{* * *} P<0.001 ;{ }^{*} P<0.05$

"Loss of soil in a rain simulator measured for the estimation of aggregate stability (AS) 


\section{Conclusions}

Soil carbohydrates represented a significant pool of the soil organic matter (5-12\% of the total organic $\mathrm{C}$ ) in the three studied forests developed under a Humic Cambisol within the Spanish humid temperate zone. A total of 90 $\%$ of the neutral sugars came from the more labile non-cellulosic polysaccharides whereas the neutral sugars from the more recalcitrant cellulosic polysaccharides represented only $10 \%$, hexoses predominating over pentoses in these two fractions of different lability.

The size and composition of the carbohydrate pool significantly varied with the season of the year, the type of vegetation and the interaction between these factors. The type of vegetation was the most important factor of variation for the neutral sugars, followed by the sampling time and the interaction of both factors.

The content of hexoses, pentoses and neutral sugars in the three forests showed the same behaviour pattern, exhibiting values that followed the order: Quercus > Pinus > Eucalyptus, with important seasonal fluctuations, the maximum values being found in spring and winter and the minimum in autumn and summer.

The establishment of a Pinus or a Eucaliptus forest in the Atlantic soil after deforestation of part of the old oak climax forest developed over the same soil, considerably reduced the SOM (C and $\mathrm{N}$ ), including the carbohydrate labile pool, as well as the aggregate stability, causing a decrease of the soil quality.

\section{Acknowledgements}

The authors thank J. Salmonte and B. Arnaiz for technical assistance. This work was supported by two grants (08MR4002400PR and AGL200802823) from the Consellería de Educación y Ordenación Universitaria de la Xunta de Galicia and the Comisión Interministerial de Ciencia y Tecnología (CICYT), Spain, respectively. 


\section{REFERENCES}

- Álvarez E, Torrado VM, Fernández-Marcos ML, Díaz-Raviña M. 2009. Microbial biomass and activity in a forest soil under different tree species. Elec. J. Environ. Agric. Food Chem. 8:878-887.

- Angers DA, Nadeau P, Mehuys GR. 1988. Determination of carbohydrate composition of soil hydrolysates by high-performance liquid chromatograph. J. Chromat. 454:444-449.

- Benzing-Purdie L. 1980. Organic matter and carbohydrate distribution in an Orthic Humic Gleysol. Soil. Biol. Biochem. 12:567-571.

- Carballas T, Martín A, Díaz-Raviña M. 2009. Efecto de los incendios forestales sobre los suelos de Galicia. In: Cerdà A, Mataix-Solera J, editors. Efectos de los incendios forestales sobre los suelos en España. El estado de la cuestión visto por los científicos españoles. Valencia: Cátedra Divulgación de la Ciencia, Universitat de Valencia. p. 269-301.

- Cheshire MV. 1979. Nature and origin of carbohydrates in soils. London: Academic Press.

- Cheshire MV. 1985. Carbohydrates in relation to soil fertility. In: Vaughan D, Malcolm RE, editors. Soil organic matter and biological activity. Dordrecht: Martinus Nijhoff DR and Junk W. p. 263-288.

- Cheshire MV, Sparling GP, Mundie CM. 1984. Influence of soil type, crop and air drying on residual carbohydrate content and aggregate stability after treatment with periodate and tetraborate. Plant Soil 76:339-347.

- Currie WS, Aber JD, Mcdowell WH, Boone RD, Magill $\mathrm{AH}$. 1996. Vertical transport of dissolved organic $\mathrm{C}$ and $\mathrm{N}$ under long-term $\mathrm{N}$ amendments in pine and hardwood forest. Biogeochemistry 36:471-505.

- Debosz K, Vognsen L, Labouriau R. 2002. Carbohydrates in hot water extracts of soil aggregates as influenced by long-term management. Commun. Soil Sci. Plant Anal. 33:623-634.

- Díaz-Raviña M, Carballas T, Acea MJ. 1988. Microbial biomass and metabolic activity in four acid soils. Soil Biol Biochem. 20:817-823.

- Díaz-Raviña M, Carballas T, Acea MJ. 1995. Seasonal changes in microbial biomass and nutrient flush in forest soil. Biol. Fert. Soils 19:220-226.
- Doutre DA, Hay GW, Hood A, Van Loon GW. 1978. Spectrophotometric methods to determine carbohydrates in soil. Soil Biol. Biochem. 10:457-462.

- Folsom BL, Wagner JH, Scrivner CL. 1974. Comparison of soil carbohydrates in several prairie and forest soils by gas-liquid chromatography. Soil Sci. Soc. Am. Proc. 38:305-309.

- González-Prieto SJ, Cabaneiro A, Villar MC, Carballas M, Carballas T. 1996. Effect of soil characteristics on $\mathrm{N}$ mineralization capacity in 112 native and agricultural soils from the northwest of Spain. Biol. Fert. Soils 22:252-260.

- González-Prieto SJ, Villar MC. 2003. Soil organic N dynamics and stand quality in $P$. radiata pinewoods of the temperate humid region. Soil Biol. Biochem. 35:1395-1404.

- Gregorich E, Carter MR, Angers DA, Monreal CM, Ellert BH. 1994. Towards a minimum data set to asses soil organic matter quality in agricultural soils. Can. J. Soil. Sci. 74:367-385.

- Guckert A, Jacquin F. 1973. Intéractions climat, matière organique et stabilité structurale en sols limoneux. Bull. E.N.S.A.I.A. Nancy XV:47-67.

- Guitián Ojea F, Carballas Fernández T. 1976. Técnicas de Análisis de Suelos. Santiago de Compostela: Pico Sacro.

- Haynes RJ. 2000. Labile organic matter as an indicator of organic matter quality in arable and pastoral soils in New Zealand. Soil Biol Biochem. 32:211-219.

- Haynes RJ, Francis GS. 1993. Changes in microbial biomass $\mathrm{C}$, soil carbohydrate composition and aggregate stability induced by growth of selected crop and forage species under field conditions. J. Soil Sci. 44:665-675.

- Jacquin F, Carballas M, Carballas T. 1978. Interaction entre les ions aluminium et la minéralisation de la matière organique dans les soils humifères atlantiques. C. R. Acad. Sci. Paris 286 (Série D):511-514.

- Joergensen RG, Meyer B. 1990. Chemical change in organic matter decomposing on a forest Rendzina under beech (Fagus sylvatica L.). J. Soil Sci. 41:17-21.

- Jolivet C, Angers DA, Chantigny MH, Andreux F, Arrouays D. 2006. Carbohydrate dynamics in particlesize fractions of sandy spodosols following forest conversion to maize cropping. Soil Biol. Biochem. 38:2834-2842. 
- Kaiser K, Guggenberger G, Haumaier L, Zech W. 2001. Seasonal variations on the chemical composition of dissolved organic matter in organic forest floor layer leachates of old growth Scots pine (Pinus sylvestris L.) and European beech (Fagus sylvatica L.) stand in northeastern Bavaria, Germany. Biogeochemistry 55:103-143.

- Kalbitz K, Schmerwitz D, Schwesig D, Matzner E. 2003. Biodegradation of soil-derived dissolved organic matter as related to its properties. Geoderma 113:273-291.

- Kavdir Y, Ekinci H, Yüksel Q, Mermut AR. 2005. Soil aggregate stability and ${ }^{13} \mathrm{C}-\mathrm{CP} / \mathrm{MAS}-\mathrm{NMR}$ assessment of organic matter in soils influenced by forest wildfires in Çanakkale, Turkey. Geoderma 129:219229.

- Kawahigashi M, Sumida H, Yamamoto K. 2003. Seasonal changes in organic compounds in soil solutions obtained from volcanic ash soils under different land uses. Geoderma 113:381-396.

- Larré-Larrouy MC, Blanchart E, Albrecht A, Feller C. 2004. Carbon and monosaccharides of a tropical Vertisol under pasture and market-gardening: distribution in secondary organomineral separates. Geoderma 119:6163-178.

- Lu G, Sakagami K, Tanaka H, Hamada R. 1998. Role of soil organic matter in stabilization of water-stable aggregates in soils under different types of land use. Soil Sci. Plant. Nutr. 44:147-155.

- Martín A, Diaz-Raviña M, Carballas T. 2009. Evolution of composition and content of soil carbohydrates following forest wildfires. Biol. Fertil. Soils 45:511520.

- Martín A, Diaz-Raviña M, Carballas T. 2011. Shortand medium term evolution of soil properties in Atlantic forest ecosystems affected by wildfires. Land Degrad. Develop. doi:10.1002/ldr.1078.

- Murata T, Nagaishi N, Hamada R, Tanaka H, Sakagami K, Kato T. 1998. Relationship between soil neutral sugar composition and the amount of labile soil organic matter in Andisol treated with bark compost or leaf litter. Biol. Fertil. Soils 27:342-348.

- Murata T, Tanaka H, Yasue S, Hamada R, Sakagami K, Kurokawa Y. 1999. Seasonal variations in soil microbial biomass content and soil neutral sugar composition in grassland in the Japanese temperate zone. Appl. Soil Ecol. 11:253-259.
- Murayama S. 1980. The monosaccharide composition of polysaccharides in Andosoils. J. Soil Sci. $31: 481-490$

- Murayama S. 1984. Decomposition kinetics of straw saccharides and synthesis of microbial saccharides under field conditions. J. Soil Sci. 35:231-242.

- Oades JM. 1984. Soil organic matter and structural stability: Mechanisms and implications for management. Plant Soil 76:319-337.

- Oades JM, Kirkman MA, Wagner GH. 1970. The use of gas-liquid chromatography for the determination of sugars extracted from soil by sulfuric acid. Soil. Sci. Soc. Am. Proc. 34:230-235.

- Puget P, Angers DA, Chenu C. 1999. Nature of carbohydrates associated with water-stable aggregates of two cultivated soils. Soil Biol. Biochem. 31:55-63.

- Rovira P, Vallejo VR. 2002. Labile and recalcitrant pools of carbon and nitrogen in organic matter decomposing at different depths in soil: an acid hydrolysis approach. Geoderma 107:109-141.

- Rovira P, Vallejo R. 2007. Labile, recalcitrant and inert organic matter in Mediterranean forest soils. Soil Biol. Biochem. 39:202-215.

- Schnitzer M. 1991. Soil organic matter. The next 75 years. Soil Sci. 51:41-58.

- Soto B, Benito E, Díaz-Fierros F. 1991. Heat-induced degradation processes in forest soils. Int. J. Wildland Fire 1:147-152.

- Spielvogel S, Prietzel J, Kögel-Knabner I. 2007. Changes in lignin, phenols and neutral sugars in different soil types of a high-elevation forest ecosystem 25 years after forest dieback. Soil Biol. Biochem. 39:655-668

- Stevenson FJ. 1982. Soil carbohydrates. In: Stevenson FJ, editor. Humus chemistry, genesis, composition, reactions. New York: John Wiley. p. 146-171.

- Tanaka H, Murata T, Sakagami K, Hamada R. 1995. Relationship between neutral sugars and the degree of humification in andisols. Soil Sci. Plant Nutr. 41:753-761.

- Thomas RL, Lynch DL. 1961. A method for the quantitative estimation of pentoses in soil. Soil Sci. 91:312-316. 
- van Hees PAW, Johansson E, Jones DL. 2008. Dynamics of simple carbon compounds in two forest soils as revealed by soil solution concentrations and biodegradation kinetics. Plan Soil 310:11-23.

- World Reference Base for Soil Resources (WRB). 2007. A framework for international classification, correlation and communication. World soil resources reports No. 103. Roma: FAO. 